\title{
Дерматоліпектомія у паціентів із післяопераційною вентральною грижею за умов морбідного ожиріння
}

\begin{abstract}
Мета роботи: розпрацювати тактичні передумови виконання реконструктивної абдомінопластики та герніопластики з імовірними варіантами корекції м’язово-апоневротичного шару передньої черевної стінки та адекватним вибором сітчастого імпланта та з урахуванням анатомічних і функціональних змін у ділянці операційного втручання.

Матеріали і методи. Проаналізовано результати хірургічного лікування 46 пацієнтів із післяопераційною вентральною грижею (ПОВГ) та супутнім морбідним ожирінням за умов одночасного виконання алогерніопластики та дерматоліпектомії, з урахуванням результатів проведеного дослідження особливостей кровопостачання підшкірно-жирового шару передньої черевної стінки у хворих із різним IMT. Вивчення гемодинаміки передньої черевної стінки у хворих із різним IMT дозволило нам визначити ділянки з інтенсивним та менш інтенсивним кровопостачанням, дослідити судини з різним діаметром та швидкістю кровотоку. Це стало доказовою базою вибору площі щадної мобілізації підшкірно-жирової клітковини під час виконання дерматоліпектомії. Результати досліджень та їх обговорення. В осіб з наявним III та IV ст. ожиріння з IMT=30-40 та $>40$ відмічено високий рівень кровотоку в мезо-гіпогастральній ділянці, особливо в ділянці грижових воріт, у надлобковій та пахових ділянках, із достовірно низьким рівнем кровопостачання та значним послабленням трофіки тканин на рівні вище пупка аж до реберних дуг. Водночас у хворих на ожиріння III ст. та морбідне ожиріння IV ст. найактивніша візуалізація судин визначалась у нижніх відділах передньої черевної стінки, діаметр судин значно збільшувався, як і кількість судин із венозним типом кровотоку. Етап дерматоліпектомії виконували в основному за методиками Küster 10 (21,8 \%) пацієнтам із вертикальним висіченням шкіри 3 підшкірно-жировою клітковиною, Jolly, Thorek - 32 (69,6 \%) пацієнтам з видаленням тканин гіпогастральної ділянки горизонтальним доступом; у хворих із вираженим надлишком шкіри передньої черевної стінки виконували дерматоліпектомію комбінованим Т-подібним доступом за Castansres-Goethel - 4 (8,7 \%). Вважаємо перспективним виконання симультанної дерматоліпектомії при алогерніопластиці з приводу ПОВГ при морбідному ожирінні з урахуванням особливостей кровопостачання підшкірно-жирової клітковини передньої черевної стінки та за умов зменшення площі скелетування підшкірно-жирового шару та виконання менш травматичної вертикальної, нижньої горизонтальної, в рідкісних випадках - комбінованої дерматоліпектомії, що, в свою чергу, мінімізує ризики виникнення післяопераційних ускладнень.
\end{abstract}

Ключові слова: післяопераційна вентральна грижа; морбідне ожиріння; дерматоліпектомія.

Постановка проблеми і аналіз останніх досліджень та публікацій. Проблема хірургічного лікування хворих на післяопераційну вентральну грижу є досить актуальною [3, 4]. Актуальність ії зумовлена зростаючою кількістю пацієнтів із даною патологією та високим числом рецидивувань при виконанні реконструктивних операційних втручань (4,3-46 \%) [5, 7, 8], а при великих і гігантських ПОВГ кількість рецидивувань складає 60 \% випадків [10]. Щорічно в світі виконується близько 20 мільйонів операцій з приводу черевних гриж, а в Україні - до 9000, що складає від 10 до 15 \% усіх виконаних хірургічних втручань загалом. Кожен 8-10 пацієнт входить у групу ризику виникнення рецидиву захворювання [3]. Необхідно відмітити значне збільшення кількості хворих на післяопераційні вентральні грижі із супровідним морбідним ожирінням [2, 6, 7]. Існуюче уявлення про те, що хірург повинен займатись лікуванням лише післяопераційної грижі, а корекцію передньої черевної стінки повинен проводити пластичний хірург, поступово втрачає свої позиції і змінює свій формат на користь одномоментного виконання герніопластики та дермато- ліпектомії [11, 12]. Враховуючи значущі технічні можливості, появу величезної кількості алотрансплантатів в арсеналі хірургів, лікування післяопераційних вентральних гриж при морбідному ожирінні та висячому животі до сьогодні є однією із важливих та дискусійних проблем абдомінальної, реконструктивної та пластичної хірургії, які потребують додаткового деталізованого вивчення 3 урахуванням локальної гемодинаміки підшкірножирової клітковини передньої черевної стінки за умов ожиріння, оцінки вибору оптимального щадного виділення шкірно-жирового клаптя, з мінімальною ішемізацією залишених тканин, способу проведення герніопластики та вибору сітчастого імплантата з індивідуалізованим підходом до кожного окремо взятого пацієнта $[1,10]$.

Мета роботи: розпрацювати тактичні передумови виконання реконструктивної абдомінопластики та герніопластики з імовірними варіантами корекції м’язово-апоневротичного шару передньої черевної стінки та адекватним вибором сітчастого імпланта з урахуванням анатомічних і функціональних змін у ділянці операційного втручання. 
Матеріали і методи. 32014 до 2016 р. у клініці хірургії ННІ ПО ТДМУ імені І. Я. Горбачевського на базі хірургічного відділення Тернопільської міської лікарні № 2 прооперовано 46 пацієнтів з ПОВГ та супутнім ожирінням і морбідним ожирінням. Проліковано 42 жінки і 4 чоловіки у віці від 38 до 71 року. Середній вік пацієнтів склав $(50,4 \pm 4,5)$ року (табл. 1$)$.

Середній індекс маси тіла (IMT) у пацієнтів склав $(34,6 \pm 5,4)$ кг $/ \mathrm{M}^{2}$. Ожиріння II ступеня мало місце у 28 хворих, ожиріння III ступеня - у 16 пацієнтів, IV ступеня - у 2 пацієнтів. Усі пацієнти мали серединну локалізацію післяопераційної вентральної грижі з діаметром грижових воріт від 6 до 20 см, та з наявним першим чи другим рецидивом. За класифікацією Chevrel J. P., Rath A. M. (SWRclassification), 1999 [9] MW3R1 мали 24 хворих (52,2 \%), MW4R2 - 22 пацієнти (47,8 \%). У більшості пацієнтів (78,3 \%) була супровідна патологія (IXC, атеросклеротичний кардіосклероз, гіпертонічна хвороба, цукровий діабет та ін.). Терміни виникнення грижі коливались у межах від 3 до 12 років. Усім 46 пацієнтам у доопераційному періоді проведено загальноклінічне обстеження та ультразвукове дослідження (доплерографія) підшкірно-жирової клітковини передньої черевної стінки конвексним мультичастотним датчиком Ultima SM-30. Вивчення гемодинаміки передньої черевної стінки у хворих із різним IMT дозволило нам визначити ділянки з інтенсивним та менш інтенсивним кровопостачанням, дослідити судини з різним діаметром та швидкістю кровотоку. Це стало доказовою базою вибору площі щадної мобілізації підшкірно-жирової клітковини під час виконання дерматоліпектомії.

Результати досліджень та їх обговорення. Важливим, на наш погляд, за даними отриманих досліджень, є майже рівномірний розподіл гемо- динаміки в усіх ділянках передньої черевної стінки у пацієнтів з II ст. ожиріння. В осіб із наявними III та IV ст. ожиріння з IMT=30-40 та $>40$ відмічено високий рівень кровотоку в мезогіпогастральній ділянці, особливо в ділянці грижових воріт, в надлобковій та пахових ділянках, із достовірно низьким рівнем кровопостачання та значним послабленням трофіки тканин на рівні вище пупка аж до реберних дуг. У 28 хворих з ожирінням II ступеня в підшкірно-жировій клітковині виявлено поодинокі дрібні судини діаметром $((1,1 \pm 0,8)$ мм) з артеріальним типом кровотоку. Водночас у пацієнтів з ожирінням III ст. та морбідним ожирінням IV ст. найактивніша візуалізація судин визначалась в нижніх відділах передньої черевної стінки, діаметр судин значно збільшувався, як і кількість судин з венозним типом кровотоку (табл. 2).

35 (76,1 \%) хворим виконано ретромускулярну алогерніопластику типу “Sub lay”. 6 (13,0%) хворим алогерніопластику проведено методом “In lay”. У 2 (4,3 \%) пацієнтів з метою відновлення анатомічної цілісності передньої черевної стінки, проте без загрози виникнення АКС, алогерніопластику довелось доповнити етапом виконання TAR (transversus abdominis release). 5 пацієнтам за відсутністю технічних умов, а саме з вираженою ригідністю країв грижових воріт (10,9 \%) виконано алогерніопластику за типом “On lay” (табл. 3).

Етап дерматоліпектомії виконували в основному за методиками Küster у 10 (21,8 \%) пацієнтів з вертикальним висіченням шкіри з підшкірно-жировою клітковиною, Jolly, Thorek - у 32 (69,6 \%) із видаленням тканин гіпогастральної ділянки горизонтальним доступом, та у 4 (8,7 \%) хворих із вираженим надлишком шкіри передньої черевної стінки виконували дерматоліпектомію комбінованим Т-подібним доступом за Castansres-Goethel (табл. 4).

5 (10,9 \%) хворим алогерніопластику проведено 3 використанням поліпропіленової сітки фір-

Таблиця 1. Розподіл пацієнтів за статтю і віком (n=46)

\begin{tabular}{||l|c|c|c|c|c|c||}
\hline \multirow{2}{*}{ Стать } & \multicolumn{7}{|c||}{ Вік } \\
\cline { 2 - 8 } & 30-39 років & $40-49$ років & $50-59$ років & $60-69$ років & $70-79$ років & Разом \\
\hline Чоловіки & 1 & 2 & 1 & - & - & 4 \\
\hline Жінки & 6 & 12 & 16 & 7 & 1 & 42 \\
\hline Усього & 7 & 14 & 17 & 7 & 1 & 46 \\
\hline
\end{tabular}

Таблиця 2. Показники кровотоку підшкірно-жирової клітковини передньої черевної стінки у пацієнтів із різним індексом маси тіла (IMT)

\begin{tabular}{||l|c|c||}
\hline \hline \multicolumn{1}{|c||}{ Групи пацієнтів із різним IMT } & $\begin{array}{c}\text { Максимальна швидкість } \\
\text { кровотоку Vmax (см/с) }\end{array}$ & $\begin{array}{c}\text { Діаметр } \\
\text { судин (мм) }\end{array}$ \\
\hline II ст. - 3 надлишковою масою (IMT=25-30) & $4,60 \pm 2,65$ & $1,1 \pm 0,8$ \\
\hline III ст. - з наявним ожирінням (IMT=30-40) & $6,55 \pm 9,4$ & $1,63 \pm 1,1$ \\
\hline IV ст. - 3 наявним морбідним ожирінням (IMT>40) & $8,20 \pm 5,35$ & $1,92 \pm 0,84$ \\
\hline
\end{tabular}


Таблиця 3. Тип виконаної алогерніопластики у пацієнтів із різним індексом маси тіла (IMT)

\begin{tabular}{|c|c|c|c|c|c|c|}
\hline \multirow{3}{*}{$\begin{array}{c}\text { Тип операційного } \\
\text { втручання }\end{array}$} & \multicolumn{6}{|c|}{ І Індекс маси тіла } \\
\hline & \multicolumn{2}{|c|}{$\begin{array}{c}\text { II ст. - } 3 \text { надлишковою } \\
\text { масою (IMT=25-30) }\end{array}$} & \multicolumn{2}{|c|}{$\begin{array}{c}\text { III ст. - } 3 \text { наявним } \\
\text { ожирінням (IMT=30-40) }\end{array}$} & \multicolumn{2}{|c|}{$\begin{array}{c}\text { IV ст. - } 3 \text { наявним морбідним } \\
\text { ожирінням (IMT>40) }\end{array}$} \\
\hline & абс. & $\%$ & абс. & $\%$ & абс. & $\%$ \\
\hline "On lay" & 2 & 7,1 & 2 & 12,5 & 1 & 50 \\
\hline "Sub lay" & 24 & 85,8 & 11 & 68,7 & - & - \\
\hline "In lay" & 2 & 7,1 & 3 & 18,8 & 1 & 50 \\
\hline Всього & 28 & 100,0 & 16 & 100,0 & 2 & 100,0 \\
\hline
\end{tabular}

Таблиця 4. Тип виконаної дерматоліпектомії у пацієнтів із різним індексом маси тіла (IMT)

\begin{tabular}{|c|c|c|c|c|c|c|}
\hline \multirow{3}{*}{$\begin{array}{c}\text { Тип виконаної } \\
\text { дерматоліпектомії }\end{array}$} & \multicolumn{6}{|c|}{ Індекс маси тіла } \\
\hline & \multicolumn{2}{|c|}{$\begin{array}{c}\text { II ст. - } 3 \text { надлишковою } \\
\text { масою (IMT=25-30) }\end{array}$} & \multicolumn{2}{|c|}{$\begin{array}{c}\text { III ст. - } 3 \text { наявним } \\
\text { ожирінням (IMT=30-40) }\end{array}$} & \multicolumn{2}{|c|}{$\begin{array}{c}\text { IV ст. - } 3 \text { наявним морбідним } \\
\text { ожирінням (IMT>40) }\end{array}$} \\
\hline & абс. & $\%$ & абс. & $\%$ & абс. & $\%$ \\
\hline Küster & 5 & 17,8 & 3 & 18,75 & 2 & 100,0 \\
\hline Jolly, Thorek & 23 & 82,2 & 9 & 56,25 & - & 0 \\
\hline Castansres - Goethel & - & 0 & 4 & 25,0 & - & 0 \\
\hline Всього & 28 & 100,0 & 16 & 100,0 & 2 & 100,0 \\
\hline
\end{tabular}

ми “УКРТЕХМЕД” Омега-4 стандарт із діаметром поліпропіленової нитки 0,12 мм, товщиною 0,47 мм, питомою щільністю 115 г/м², у 41 (89,1%) пацієнта використано легку поліпропіленову сітку “УКРТЕХМЕД” Омега-2 стандарт із діаметром поліпропіленової нитки 0,12 мм, товщиною

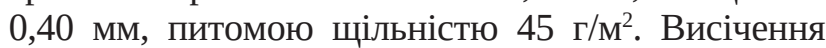
шкірно-жирового клаптя проводили під ретельним контролем гемостазу, який здійснювали за допомогою біполярного пінцета електрокоагулятором EMED ES Vision із постійним зрошенням м'язовоапоневротичних тканин передньої черевної стінки холодним стерильним фізіологічним розчином. Це, своєю чергою, зводить до мінімуму опік тканин та зменшує зону коагуляційного некрозу, при цьому забезпечуючи надійний гемостаз. Перед зашиванням шкіри ранову поверхню на всьому протязі промивали розведеним розчином бетадину. Підшкірно-жирову клітковину в декількох місцях фіксували до м’язово-апоневротичного шару передньої черевної стінки. Краї шкіри зашивали рідкими окремими вузловими швами лише до зведення її країв. Операційне втручання закінчували постановкою активного дренажу в термінах від 3 до 5 діб. У післяопераційному періоді усі хворі отримували антибіотикопрофілактику протягом 5-ти діб, розчин диклоберлу 75 мг 3,0 внутрішньом'язово та лімфоміазот Н 1,1 мл внутрішньом’язово. Бандажування пацієнтів здійснювали лише при активації останніх на 1-шу післяоперційну добу. У спокої компресійний бандаж не використовували. 3 2-ї післяопераційної доби на передню черевну стінку накладали півспиртовий компрес. 3 метою ранньої діагностики ексудативних ускладнень у ранньому післяопераційному періоді виконували УЗД контроль. Наявність сером діагностовано у 4 (8,7 \%) пацієнтів із різними ступенями IMT, проте найбільший відсоток 6,5 \% їх виявлено у пацієнтів з III ст. ожиріння (IMT=30-40) та морбідним ожирінням (IMT>40) при виконанні алогерніопластики за типом “On lay” (рис. 1).

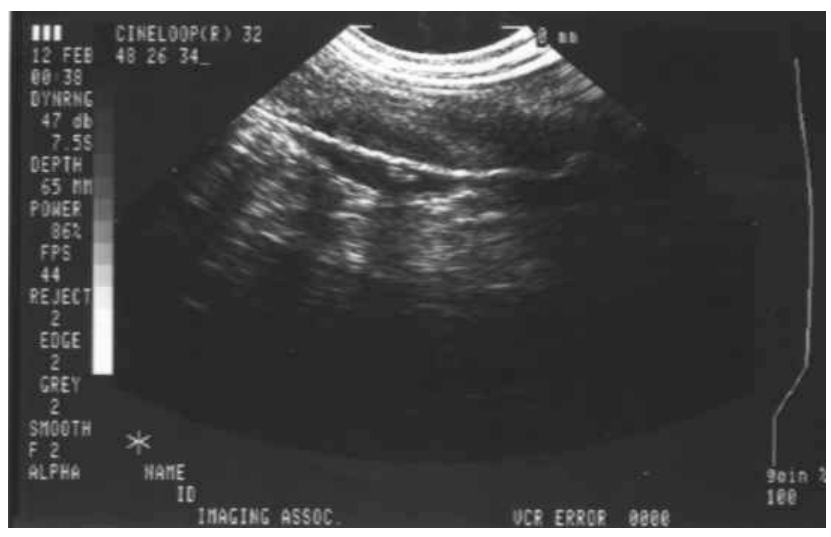

Рис. 1. Ультразвукова діагностика сероми на 5-ту післяопераційну добу, яка локалізується над і під сіткою, при виконанні алогерніопластики за типом “On lay”.

Тривала лімфорея мала місце у 5 (10,9 \%) оперованих з III та IV ст. ожиріння за умов виконання пластики грижового дефекту за типом “On lay” та дерматоліпектомії за Castansres-Goethel з використанням важкої сітки фірми “УКРТЕХМЕД” Омега-4 стандарт із діаметром поліпропіленової нитки 0,12 мм, товщиною 0,47 мм, порівняно 3 групою пацієнтів, яким проведена менш травматична поперечна дерматоліпектомія за Jolly, Thorek та алопластика "Sub lay" та “In lay”, легкою сіткою Омега-2 стандарт із діаметром полі- 
пропіленової нитки 0,12 мм, товщиною 0,40 мм. Утворення інфільтрату післяопераційної рани було рівномірним майже в усіх групах обстежуваних пацієнтів, проте найбільший відсоток 3 (6,5%) спостерігався у пацієнтів з III ст. ожиріння оперованих методикою “Sub lay” та з виконанням комбінованої, більш травматичної дерматоліпектомії за Castansres-Goethel. У цій же групі оперованих мала місце і найвища кількість крайового некрозу шкіри із розходженням країв рани (5 (10,9 \%)) та нагноєнням післяопераційної рани (2 (4,3%)).

Таким чином частота виникнення ранніх післяопераційних ускладнень алогерніопластики та симультанної дерматоліпектомії частіше спостерігається серед пацієнтів із супутнім ожирінням III ст. та морбідним ожирінням за умов виконання пластики грижового дефекту за типом “On lay” та дерматоліпектомії за Küster i Castansres-Goethel. При застосуванні методик, що передбачають широку та високу мобілізацію шкірно-жирового клаптя за умов виконання герніопластики “On lay”, збільшується частота крайового некрозу шкіри з подальшим нагноєнням та розходженням країв рани. Значно кращі результати спостерігали у пацієнтів, яким виконували горизонтальну дерматоліпектомію за JollyThorek в комбінації з алогерніопластикою "Sub lay" та використанням легкої поліпропіленової сітки фірми “УКРТЕХМЕД” Омега-2 стандарт.

\section{СПИСОК ЛІТЕРАТУРИ}

1. Абдоминопластика как этап пластики рубцовых вентральных грыж у пациентов с избыточной массой тела / А. С. Никоненко, С. Н. Завгородний, Д. А. Децык [и др.] // Запорожский медицинский журнал. - 2006. - № 4. - С. 12-15. 2. Гербали О. Ю. Актуальные аспекты лечения послеоперационной грыжи живота у больных с ожирением / О. Ю. Гербали / Клініч. хірургія. - 2010. - № 3. - С. 45-49.

3. Актуальные проблемы современной герниологии / В. Ф. Саенко, Л. С. Белянский // Клин. хирургия. - 2003. № 11. - С. 3-5.

4. Хірургічна тактика у хворих з гігантськими дефектами черевної стінки / Л. С. Білянський, І. М. Тодуров, С. В. Косюхно [та ін.] // Український журнал хірургії. - 2011. - № 2 (11). - C. 19-24.

5. Грижа як ускладнення лапароскопічних операцій / М. І. Тутченко, О. В. Васильчук, С. М. Піотрович, О. В. Мамонтов // Український журнал хірургії. - 2013. - № 2 (21). C. 99-101.

6. Лаврик А. С. Хірургічне лікування ожиріння / А. С. Лаврик, О. С. Тивончук, О. А. Лаврик // Здоров’я України. - 2013. - № 1. - C. 10-11.
Висновки. 1. Вважаємо перспективним виконання симультанної дерматоліпектомії при алогерніопластиці з приводу ПОВГ при морбідному ожирінні з урахуванням особливостей кровопостачання підшкірно-жирової клітковини передньої черевної стінки та за умов зменшення площі скелетування підшкірно-жирового шару й виконання менш травматичної вертикальної, нижньої горизонтальної, в рідкісних випадках комбінованої дерматоліпектомії, що, своєю чергою, мінімізує ризики виникнення післяопераційних ускладнень.

2. Проведений аналіз частоти виникнення ранніх післяопераційних ускладнень дозволяє стверджувати переваги виконання алогерніопластики "Sub lay" та "In lay", порівняно з герніопластикою за типом “On lay” при виконанні симультанної дерматоліпектомії у хворих з ожирінням.

3. Аналіз результатів лікування хворих із післяопераційними вентральними грижами за умов морбідного ожиріння висвітлює певні переваги застосування легких сіток типу Омега-2 стандарт фірми “УКРТЕХМЕД” з огляду на найнижчий (за нашими даними) ризик ранніх післяопераційних ускладнень. Водночас неабияким чинником має бути доступність операційних втручань, що є суттєвим у якості надання хірургічної допомоги даній категорії пацієнтів.

7. Лечение гигантских послеоперационных вентральных грыж у пациентов с морбидным ожирением / К. М. Аутло, А. Л. Янин, Е. В. Кручинина, В. В. Иванов // Материалы Пятого российского симпозиума с международным участием. Самара, 2009. - С. 20.

8. Фелештинський Я. П. Сучасні способи хірургічного лікування післяопераційних гриж живота / Я. П. Фелештинський // Здоров’я України. - 2012. - С. 24-27.

9. Chevrel J. P. Classification of incisional hernias of the abdominal wall / J. P. Chevrel, A. M. Rath // Hernia. - 2000. Vol. 1. - Vol. 1-7.

10. Incisional ventral hernias: Review of the literature and recommendations regarding the grading and technique of repair / K. Breuing, E. Charles Butler, S. Ferzoco [et al.] // Surgery. 2010. - Vol. 148, № 3. - P. 544-558.

11. Hurwitz Z. M. Pearls and pitfalls of a abdominal wall anatomy in component separation / Z. M. Hurwitz, J. O’Brien, R. M. Dunn // Hernia. - 2011. - Vol. 15, Suppl. 2. - P.3.

12. Raghavendra S. Management of ventral hernias in bariatric surgery / S. Raghavendra, P. Gentileschi, S. Kini // Surg. Obes. Relat. Dis. - 2011. - Vol. 7. - P. 110-116. 


\section{REFERENCES}

1. Nykonenko, A.S., Zavhorodniy, S.N., Detsyk, D.A., Golovko, N.H., Rusanov, Y.V., Klymenko, A.V., \& Haydarzhy, E.Y. (2006). Abdominoplastika kak etap plastiki rubtsovykh ventralnykh gryzh $\mathrm{u}$ patsyentov $\mathrm{s}$ izbytochnoy massoy tela. [Abdominoplasty as a stage of plasty of scar ventral hernias in patients with overweight]. Zaporozhskiy medytsynskiy zhurnal Zaporozhye Medical Journal, 4, 12-15 [in Russian].

2. Gerbali, O.Yu. (2010). Aktualnye aspekty lecheniya posleoperatsyonnoy gryzhy zhyvota u bolnykh s ozhyreniem [Actual aspects of the treatment of postoperative abdominal hernia in patients with obesity]. Klinichna Khirurhiya - Clinical Surgery, 3, 45-49 [in Russian].

3. Saenko, V.F., \& Belyanskiy, L.S. (2003). Aktualnye problemy sovremennoy gerniologii [Actual problems of modern gerniology]. Klinichna Khirurhiya - Clinical Surgery, 11, 3-5 [in Russian].

4. Bilyanskyi, L.S., Todurov, I.N., Kosiukhno S.V. (2011). Khirurhichna taktyka u khvorykh z hihantskymy defektamy cherevnoi stinky [Surgical tactics in patients with giant abdominal wall defects]. Ukrainskyi zhurnal khirurhii - Ukrainian Journal of Surgery, 2 (11), 19-24 [in Ukrainian].

5. Tutchenko, M.I., Vasylchuk, O.V., Piotrovych, S.M., \& Mamontov, O.V. (2013). Hryzha yak uskladnennia laparoskopichnykh operatsii [Hernia as a complication of laparoscopic surgery]. Ukrainskyi zhurnal khirurhii - Ukrainian Journal of Surgery, 2, (21), 99-101 [in Ukrainian].
6. Lavryk, A.S., Tyvonchuk, O.S., \& Lavryk, O.A. (2013). Khirurhichne likuvannia ozhyrinnia [Surgical treatment of obesity]. Zdorovia Ukrainy-Health of Ukraine, 1, 10-11 [in Ukrainian]. 7. Autlo, K.M., Yanin, A.L., Kruchynina, E.V., \& Ivanov, V.V. (2009). Lecheniye gigantskikh posleoperatsyonnykh ventralnykh gryzh u patsiyentov s morbydnym ozhyrenyem [Treatment of giant postoperative ventral hernias in patients with morbid obesity]. Materialy Pyatogo rossiyskogo simpoziuma s mezhdunarodnym uchastiyem - Materials of the Fifth Russian Symposium with International Participation, (p. 20), Samara, [in Russian].

8. Feleshtynskyi, Ya.A. (2012). Suchasni sposoby khirurhichnoho likuvannia pisliaoperatsiynykh hryzh zhyvota [Modern methods of surgical treatment of postoperative abdominal hernias]. Zdorovia Ukrainy - Health of Ukraine, 24-27 [in Ukrainian].

9. Chevrel, J.P., \& Rath, A.M. (200). Classification of incisional hernias of the abdominal wall. Hernia, 1, 1-7.

10. Breuing K., Charles E. Butler, \& Ferzoco S. (2010). Incisional ventral hernias: Review of the literature and recommendations regarding the grading and technique of repair. Surgery, 148 (3), 544-558.

11. Hurwitz, Z. M. O’Brien, J., \& Dunn R.M. (2011). Pearls and pitfalls of abdominal wall anatomy in component separation. Hernia, 15 (2), 3.

12. Raghavendra, S., Gentileschi, P., \& Kini S. (2011). Management of ventral hernias in bariatric surgery. Surg. Obes. Relat. Dis., 7, 110-116.

\section{V.I. PIATNOCHKA}

I. Horbachevsky Ternopil State Medical University

\section{DERMATOLIPECTOMY IN PATIENTS WITH POSTOPERATIVE VENTRAL HERNIA UNDER MORBID OBESITY}

The aim of the work: to develop the tactical preconditions of reconstructive abdomenoplasty and hernia repair with possible correction options of musculo-aponeurotic layer of the anterior abdominal wall and an adequate choice of the mesh implant, and taking into account the anatomical and functional changes in the field of surgery.

Materials and Methods. We analyzed results of surgical treatment of 46 patients with postoperative ventral hernia (POVH) with concomitant morbid obesity in terms both of the allogernioplasty and dermatolipectomy and, taking into account the results of the studies of the blood supply to the subcutaneous fat layer of the anterior abdominal wall in patients with different BMI. The study of hemodynamics of the anterior abdominal wall in patients with different BMI allowed us to identify areas with intensive and less intensive blood supply, research vessels with different diameter and blood velocity. This was the evidence based area selection gentle mobilization of subcutaneous fat in the performance of dermatolipectomy.

Results and Discussion. In patients with existing III and IV obesity state with a BMI of 30-40 and >40 marked by a high level of blood flow in meso-hyipogastric area, especially in the field of hernial ring, suprapubic and groin area, with significantly low blood supply and a significant weakening of the trophic tissue at a level above the navel to the costal arches. At the same time in patients with III degree obesity and IV stage morbid obesity century the most active visualization of vessels was defined in the lower anterior abdominal wall, the diameter of the vessels was significantly increased as the number of vessels with venous blood type. Dermatolipectomy was performed mainly according Küster methods in 10 (21.8\%) patients with a vertical excision of skin with subcutaneous fat, Jolly, Thorek in 32 (69.6 \%) patients with the removal of tissues by horizontal access, and in patients with severe anterior abdominal skin excess wall dermatolipectomy was performed combined with like T-access after Castansres-Goethel 4 (8.7 \%). We believe a promising performance of simultaneous dermatolipectomy at allogernioplasty about POVH under morbid obesity, taking into account peculiarities of blood supply to the subcutaneous fat of the anterior abdominal wall by reducing the area skeleting subcutaneous fat layer and performing a vertical less traumatic, lower horizontal, in rare cases, combined dermatolipectomy that in turn minimizes the risk of postoperative complications.

Key words: postoperative ventral hernia; morbid obesity; dermatolipectomy. 


\section{В. И. ПЯТНОЧКА}

ГВУЗ “Тернопольский государственный медицинский университет имени И. Я. Горбачевского”

\section{ДЕРМАТОЛИПЭКТОМИЯ У ПАЦИЕНТОВ С ПОС.ЕОПЕРАЦИОННОЙ ВЕНТРАЛЬНОЙ ГРЫЖЕЙ В УС.ЛОВИЯХ МОРБИДНОГО ОЖИРЕНИЯ}

Цель работы: разработать тактические предпосылки выполнения реконструктивной абдоминопластики и герниопластики с вероятными вариантами коррекции мышечно-апоневротического слоя передней брюшной стенки и адекватным выбором сетчатого импланта и с учетом анатомических и функциональных изменений в области оперативного вмешательства.

Материалы и методы. Проанализированы результаты хирургического лечения 46 пациентов с послеоперационной вентральной грыжей (ПОВГ) с сопутствующим морбидным ожирением в условиях одновременного выполнения аллогерниопластики и дерматолипэктомии, с учетом результатов проведенного исследования особенностей кровоснабжения подкожно-жирового слоя передней брюшной стенки у больных с различным ИМТ. Изучение гемодинамики передней брюшной стенки у больных с различным ИМТ позволило нам определить участки с интенсивным и менее интенсивным кровоснабжением, исследовать сосуды с разным диаметром и скоростью кровотока. Это стало доказательной базой выбора площади щадящей мобилизации подкожножировой клетчатки при выполнении дерматолипэктомии.

Результаты исследований и их обсуждение. У лиц с имеющейся III и IV ст. ожирения с ИМТ=30-40 и $>40$ отмечен высокий уровень кровотока в мезогипогастральной области, особенно в области грыжевых ворот, в надлобковой и паховой областях, с достоверно низким уровнем кровоснабжения и значительным ослаблением трофики тканей на уровне выше пупка до реберных дуг. В то же время у пациентов с ожирением III ст. и морбидным ожирением IV ст. наиболее активная визуализация сосудов определялась в нижних отделах передней брюшной стенки, диаметр сосудов значительно увеличивался, как и количество сосудов с венозным типом кровотока. Этап дерматолипэктомии выполняли в основном методиками Küster 10 (21,8 \%) пациентам с вертикальным иссечением кожи с подкожно-жировой клетчаткой, Jolly, Thorek - 32 (69,6 \%) пациентам с удалением тканей горизонтальным доступом; у больных с выраженным избытком кожи передней брюшной стенки выполняли дерматолипэктомию комбинированным Т-образным доступом по Castansres-Goethel - 4 (8,7 \%). Считаем перспективным выполнение симультанной дерматолипэктомии при аллогерниопластике по поводу ПОВГ в условиях морбидного ожирения с учетом особенностей кровоснабжения подкожно-жировой клетчатки передней брюшной стенки за счет уменьшения площади скелетирования подкожножирового слоя и выполнения менее травматичной вертикальной, нижней горизонтальной, в редких случаях - комбинированной дерматолипэктомии, что, в свою очередь, минимизирует риски возникновения послеоперационных осложнений.

Ключевые слова: послеоперационная вентральная грыжа; морбидное ожирение; дерматолипэктомия.

Отримано 12.01.17 